\title{
Inhibition of 3-hydroxy-3-methylglutaryl- coenzyme A reductase activity and of Ras farnesylation mediate antitumor effects of anandamide in human breast cancer cells
}

\author{
Chiara Laezza ${ }^{1,2}$, Anna Maria Malfitano ${ }^{3}$, Maria Chiara Proto ${ }^{3}$, \\ lolanda Esposito', Patrizia Gazzerro ${ }^{3}$, Pietro Formisano ${ }^{2}$, Simona Pisanti ${ }^{3}$, \\ Antonietta Santoro ${ }^{3}$, Maria Gabriella Caruso ${ }^{4}$ and Maurizio Bifulco ${ }^{3}$
}

\footnotetext{
${ }^{1}$ Institute of Endocrinology e Experimental Oncology, CNR, Via Pansini 5, 80131 Naples, Italy

${ }^{2}$ Department of Biology and Cellular, Molecular Pathology, University of Naples Federico II, Via Pansini, 80131 Naples, Italy

${ }^{3}$ Department of Pharmaceutical Sciences, University of Salerno, Via Ponte don Melillo, 84084 Fisciano, Salerno, Italy

${ }^{4}$ National Institute of Digestive Diseases, 'S. de Bellis', Castellana Grotte, 70013 Bari, Italy

(Correspondence should be addressed to C Laezza at Institute of Endocrinology e Experimental Oncology, CNR; Email: chilaez@libero.it)
}

\begin{abstract}
The endocannabinoid system regulates cell proliferation in human breast cancer cells. Recently, we described that a metabolically stable anandamide analog, 2-methyl-2'-F-anandamide, by activation of CB1 receptors significantly inhibited cell proliferation of human breast cancer cell lines. In this study, we observed that the activation of the CB1 receptor, in two human mammary carcinoma cell lines, MDA-MB-231 and MCF7, caused the inhibition of 3-hydroxy-3methylglutaryl-coenzyme A (HMG-CoA) reductase activity due to a reduction of HMG-CoA reductase transcript levels. The decrease of HMG-CoA reductase activity induced the inhibition of the prenylation of proteins, in particular of the farnesylation of Ras oncogenic protein involved in cell proliferation of these cell lines. We suggest that the inhibitory effect of anandamide analog on tumor cell proliferation could be related to the inhibition of Ras farnesylation.
\end{abstract}

Endocrine-Related Cancer (2010) 17 495-503

\section{Introduction}

The endocannabinoid system inhibits cell proliferation in various cancer cells (Bifulco \& Di Marzo 2002, Bifulco et al. 2006, 2008). We have previously described that the activation of the CB1 receptor induced the arrest of cell growth of mammary carcinoma cells by blocking the cell cycle in $\mathrm{G}_{1} / \mathrm{S}$ phase (De Petrocellis et al. 1998, Melck et al. 1999, Grimaldi et al. 2006, Laezza et al. 2006a,b). Moreover, we demonstrated that the activation of this receptor inhibited cell migration of a highly invasive human breast cancer cell line MDA-MB-231 by a RhoAROCK-dependent signaling pathway due to the inhibition of RhoA activity (Laezza et al. 2008). An important event for the biological activity of RhoA protein is a post-translational modification by an isoprenoid compound geranylgeranyl diphosphate
(GGPP). Isoprenoids are generated by the mevalonate (MVA) pathway where the endoplasmic reticulum enzyme 3-hydroxy-3-methylglutaryl-coenzyme A (HMG-CoA) reductase catalyzes the synthesis of MVA, precursor of donor isoprenoids, as farnesyl diphosphate (FPP) and GGPP that are required for the biological activity of a class of biologically relevant proteins, which include monomeric GTPase-proteins like Rho and Ras family proteins (Laezza et al. $2006 a, b)$. The rate-limiting enzyme for the synthesis of MVA is HMG-CoA reductase, a critical regulator of cell proliferation in normal as well as in tumor cells (Bifulco et al. 1995). At the transcriptional level, HMG-CoA reductase is negatively controlled by its end-product (cholesterol) since the enzyme is expressed at a relatively high rate when cells are MVA starved (Bifulco et al. 1995). Moreover, we have 
reported that in FRTL-5 rat thyroid cells, HMG-CoA reductase is transcriptionally induced by $\mathrm{TSH}$, via cAMP (Bifulco et al. 1995). TSH is the physiologic mitogen in FRTL-5 cells and when TSH starved, these cells become quiescent. TSH challenge increased HMG-CoA reductase gene expression and HMGCoA reductase activity which preceded the TSHincreased $\left[{ }^{3} \mathrm{H}\right]$ thymidine incorporation into DNA and cell doubling. We reported that TSH by increasing cAMP production induced HMG-CoA reductase gene transcription through the cAMP-responsive element (CRE) that is present in the promoter of the enzyme (Nakanish et al. 1988, Bifulco et al. 1995, Ngo et al. 2002). CRE sites were originally identified as cis-acting elements that confer transcriptional regulation in response to elevated cAMP levels (Sands \& Palmer 2008). Cannabinoids are classically documented to signal through the inhibition of adenylyl cyclase (AC). The cannabinoid $\mathrm{CB} 1$ and $\mathrm{CB} 2$ receptors are preferentially coupled to inhibitory $\mathrm{G} \alpha \mathrm{i} / \mathrm{o}$ proteins to inhibit AC activity by reducing intracellular cAMP levels (Bosier et al. 2009). Moreover, it has been described that the activation of cannabinoid receptors led to the regulation of several DNA-binding proteins, including activator protein 1 (AP-1) and the transcription factor CRE-binding protein (CREB protein; Bosier et al. 2008). In this study, we observed that the activation of $\mathrm{CB} 1$ receptor by 2-methyl-2'-Fanandamide (Met-F-AEA) inhibited the HMG-CoA reductase activity due to the decrease of HMG-CoA reductase transcript levels. This event reduced the pattern of prenylated proteins involved in the proliferation of breast cancer cells.

\section{Materials and methods}

\section{Materials}

Met-F-AEA was purchased from Calbiochem (San Diego, CA, USA). The selective CB1 antagonist, SR141716, was kindly provided by Sanofi-Aventis (Montpellier, France). 3-Hydroxy-3-methyl-3 $\left[{ }^{14} \mathrm{C}\right]$ glutaryl-CoA was supplied by Amersham; HMG-CoA sodium salt and the mevalonic acid lactone were supplied by Sigma. Glucose-6-phosphate dehydrogenase was from Calbiochem; glucose-6-phosphate disodium salt and NADP disodium salt were from Boehringer. Bisindoilmaleimide was from Alexis Corporation (San Diego, CA, USA). Anti-phosphoCREB (S133), anti-CREB were from Cell Signaling (Boston, MA, USA). Anti-Pan-Ras was from Santa Cruz Biotechnology (Santa Cruz, CA, USA), and cocktail of protease inhibitors was from Sigma.

\section{Cell culture}

MDA-MB-231, an invasive human breast carcinoma cell line, was grown in RPMI 1640 medium (Gibco BRL Life Technologies) supplemented with $10 \%$ inactivated fetal bovine serum (FBS) and $2 \mathrm{mM}$ L-glutamine (Bifulco \& Di Marzo 2002, Grimaldi et al. 2006). MCF7, a noninvasive human breast cancer cell line, was grown in DMEM supplemented with $10 \%$ inactivated FBS and $2 \mathrm{mM}$ L-glutamine (De Petrocellis et al. 1998). Cells were cultured at $37{ }^{\circ} \mathrm{C}$ in a humidified $5 \% \mathrm{CO}_{2}$ atmosphere.

\section{Proliferation assay}

The effects of Met-F-AEA on MDA-MB-231 and MCF7 proliferation were evaluated in vitro, by $\left[{ }^{3} \mathrm{H}\right]$ thymidine incorporation. The $96-$ well plates were seeded with $5 \times 10^{4}$ cells $/ \mathrm{ml}$, and the cells were immediately treated with the drugs, incubated for $24 \mathrm{~h}$ at $37^{\circ} \mathrm{C}\left(5 \% \mathrm{CO}_{2}\right)$, then pulsed with $0.5 \mu \mathrm{Ci} /$ well of $\left[{ }^{3} \mathrm{H}\right]$ thymidine, and harvested $12 \mathrm{~h}$ later. Radioactivity was measured in a scintillation counter (Wallac, Turku, Finland) (Grimaldi et al. 2006).

\section{Subcellular fractionation}

The supernatant was centrifuged at $100000 \mathrm{~g}$ for $60 \mathrm{~min}$ at $4{ }^{\circ} \mathrm{C}$. The resulting supernatant was the cytosol fraction, and the pellet was resuspended in the homogenizing buffer containing $0.2 \%$ (wt/vol) Triton $\mathrm{X}-100$. The homogenate was kept at $4{ }^{\circ} \mathrm{C}$ for $60 \mathrm{~min}$ with occasional stirring and then centrifuged at $100000 \mathrm{~g}$ for $60 \mathrm{~min}$ at $4{ }^{\circ} \mathrm{C}$. The resulting supernatant was used as the membrane fraction (Laezza et al. 2008).

\section{HMG-CoA reductase activity}

The enzyme activity was performed, following the method described by Brown et al. (1979) with slight modifications. Cells were preincubated $24 \mathrm{~h}$ before the HMG-CoA reductase assay with medium without serum and were treated with several drugs for 24 and $48 \mathrm{~h}$. Then, the cells were washed twice with $5 \mathrm{ml}$ of $0.15 \mathrm{M}$ cold $\mathrm{NaCl}$ and were harvested by scraping. The cell suspensions were homogenized and centrifuged $(900 \mathrm{~g})$ at $4{ }^{\circ} \mathrm{C}$ for $15 \mathrm{~min}$. The supernatant was then centrifuged in a $75 \mathrm{Ti}$ Beckman rotor for $30 \mathrm{~min}$ at 55400 r.p.m. $(200000 \mathrm{~g})$. The supernatant was discarded, and the pellet, containing the microsome fraction, was dissolved in $100 \mu \mathrm{l}$ of $20 \mathrm{mM}$ imidazole, $\mathrm{pH} 7.4,5 \mathrm{mM}$ dithiothreitol (DTT), and it was stored at $-80{ }^{\circ} \mathrm{C}$ until the HMG-CoA reductase assay. The HMG-CoA reductase activity was evaluated starting from $20 \mu \mathrm{l}$ microsome samples containing $20-50 \mu \mathrm{g}$ protein. The samples were preincubated for $30 \mathrm{~min}$ at 
$37{ }^{\circ} \mathrm{C}$ with $30 \mu \mathrm{l}$ of $20 \mathrm{mM}$ imidazole, $5 \mathrm{mM}$ DTT, $83 \mathrm{mM} \mathrm{MgCl}$, and 10 units/ml of Escherichia coli alkaline phosphatase. Then, $50 \mu 1$ of $0.2 \mathrm{M}$ potassium phosphate $(\mathrm{pH} 7.4), 40 \mathrm{mM}$ glucose-6-phosphate, $20 \mathrm{mM}$ disodium EDTA, $10 \mathrm{mM}$ DTT, $5 \mathrm{mM}$ NADP, and $50 \mu \mathrm{g} / \mathrm{ml}$ glucose-phosphate dehydrogenase were added to the preincubation solution. The reaction was started by adding $25 \mu \mathrm{l}$ of $5 \mathrm{mM}\left[{ }^{14} \mathrm{C}\right] \mathrm{HMG}-\mathrm{CoA}$ (specific activity $8000-9000$ c.p.m./nmol); after $30 \mathrm{~min}$ of incubation at $37{ }^{\circ} \mathrm{C}$, the $\left[{ }^{14} \mathrm{C}\right] \mathrm{MVA}$ was converted to lactone and was isolated by thin layer chromatography (Mondola et al. 2002).

\section{Reverse transcriptase-PCR}

Total RNA was isolated from liver (100-150 mg) using TRIzol. Single strand cDNA was synthesized from $2 \mu \mathrm{g}$ of total RNA, using Moloney murine leukemia viruses reverse transcriptase. The cDNAs for HMGR and $\beta 2$ microglobulin $(\beta 2 \mathrm{~m})$ (housekeeping genes) were PCR amplified using the following specific primers: HMGR (sense) 5'-TAC CAT GTC AGG GGT ACG TC-3' and (antisense) $5^{\prime}$-CCA GTC CTA ATG AAA CCT TAG AAG T- $3^{\prime} ; \beta_{2}$ MIC (sense) 5'-CCT GGA TTG CTA TGT GTC TGG GTT TCA TCC- $3^{\prime}$ and (antisense) $5^{\prime}$-GGA GCA ACC TGC TCA GAT ACA TCA AAC ATG-3' respectively. PCR amplification was carried out as follows: HMGR, $1 \times\left(95{ }^{\circ} \mathrm{C}, 1 \mathrm{~min}\right), 32 \times\left(93{ }^{\circ} \mathrm{C}, 30 \mathrm{~s} ; 61{ }^{\circ} \mathrm{C}, 45 \mathrm{~s}\right.$ and $\left.69^{\circ} \mathrm{C}, 35 \mathrm{~s}\right)$, and $1 \times\left(69^{\circ} \mathrm{C}, 5 \mathrm{~min}\right)$; and $\beta_{2} \mathrm{MIC}$, $1 \times\left(95^{\circ} \mathrm{C}, 50 \mathrm{~s}\right), 28 \times\left(93{ }^{\circ} \mathrm{C}, 30 \mathrm{~s} ; 60^{\circ} \mathrm{C}, 1 \mathrm{~min}\right.$ and $\left.69^{\circ} \mathrm{C}, 1 \mathrm{~min}\right)$, and $1 \times\left(69^{\circ} \mathrm{C}, 5 \mathrm{~min}\right)$. Amplified products were resolved by $2 \%$ agarose gel electrophoresis and were stained with ethidium bromide.

\section{Western blotting analysis}

After $24 \mathrm{~h}$ of incubation, cells were washed twice with PBS and resuspended in lysis buffer (HEPES $50 \mathrm{mM}$, $\mathrm{NaCl} 150 \mathrm{mM}$, EDTA $50 \mathrm{mM}, \mathrm{NaF} 100 \mathrm{mM}$, Na orthovanadate $2 \mathrm{mM}$, glycerol, $\mathrm{Na}_{4} \mathrm{P}_{2} \mathrm{O}_{7} 10 \mathrm{mM}$, and $10 \%$ triton, $\mathrm{pH} 7.5$ ), and they were passed through a 23-gauge needle 10 times before centrifugation at $12000 \mathrm{~g}$ at $4{ }^{\circ} \mathrm{C}$. Aliquots of the cellular lysates $(40 \mu \mathrm{g}$ of protein) were boiled for $5 \mathrm{~min}$, electrophoresed on a $10 \%$ SDS-PAGE, transferred to nitrocellulose membranes, and incubated with antibodies. The blots were blocked in PBS containing 0.1\% Tween 20 and 5\% nonfat dry milk for $1 \mathrm{~h}$ at room temperature. The filters were then probed overnight with primary specific antibodies. Immunodetection of specific proteins was carried out with HRP-conjugated donkey anti-mouse or anti-rabbit IgG (Bio-Rad), using the enhanced chemiluminescence system (Amersham).

\section{Incorporation of $\left[{ }^{3} \mathrm{H}\right]-M V A$ into cellular proteins}

Cells were incubated with drugs for $24 \mathrm{~h}$. During the last $7 \mathrm{~h}$ of incubation, $10 \mu \mathrm{M}$ lovastatin and $30 \mu \mathrm{Ci} / \mathrm{ml}$ $\left[5-{ }^{3} \mathrm{H}\right]-\mathrm{MVA}$ were added to medium. Density of cell culture ranged between 1.5 and $2.0 \times 10^{6} \mathrm{cells} / \mathrm{ml}$ in $100 \mathrm{~mm}$ Petri dishes. Cells were then washed three times with ice-cold PBS, scraped from the dish and lysed in hypotonic buffer $(10 \mathrm{mM}$ Tris- $\mathrm{HCl}, \mathrm{pH} 7.2$ plus inhibitor of protease), disrupted by sonication, and centrifuged at 3000 r.p.m. (1000g) for $10 \mathrm{~min}$ at $4{ }^{\circ} \mathrm{C}$. Equal amounts of each protein extract $(100 \mu \mathrm{g})$ were analyzed by $12 \%$ SDS-PAGE as described (Laezza et al. 2006a).

\section{Immunoprecipitation and SDS-PAGE}

$\left[{ }^{3} \mathrm{H}\right]$-MVA-labeled cells were washed three times with PBS and were lysed in RIPA buffer $(20 \mathrm{mM}$ Tris/150 mM NaCl/1 mM EDTA/0.5\% (vol/vol) nonidet P-40/0.5\% (wt/vol) $\mathrm{Na}$ deoxycholate $/ 0.1 \%$ (vol/vol) Trasylol/0.2 mM phenylmethylsulfonyl fluoride, $\mathrm{pH}$ 7.4). After $10 \mathrm{~min}$ on ice, the lysates were centrifuged at $12000 \mathrm{~g}$ for $10 \mathrm{~min}$, and the supernatants were immunoprecipitated with $5 \mu \mathrm{g}$ of preimmune rat serum or anti-pan-p21ras mAb (Santa Cruz Biotechnology) followed by incubation with protein A-Sepharose. Immunoprecipitates were washed three times with RIPA buffer and once with $100 \mathrm{mM}$ Tris-Cl (pH 6.8), and then they were dissolved in Laemmli loading buffer with $1 \mathrm{mM}$ DTT before electrophoresis in a $12.5 \%$ SDS-PAGE. Gels then were permeated with Amplify fluorographic enhancer (Amersham), and they were dried and autoradiographed at $-80^{\circ} \mathrm{C}$.

\section{Densitometric and statistical analyses}

The intensities of bands obtained from western blots and RT-PCR were estimated with Alpha ImagerTm2200 (Alpha Innotech Corporation, Santa Clara, CA, USA). All the measurements were made in triplicate, and all values are represented as mean \pm s.D. The significance of difference between the treatments and/or with the controls was obtained with Student's $t$-test. A $P$ value $<0.05$ was considered statistically significant.

\section{Results}

\section{Met-F-AEA inhibited the HMG-CoA reductase activity}

Recently, we described that Met-F-AEA, a stable analog of anandamide, inhibited the cell proliferation of MDA-MB-231 and MCF7 breast cancer cell lines 


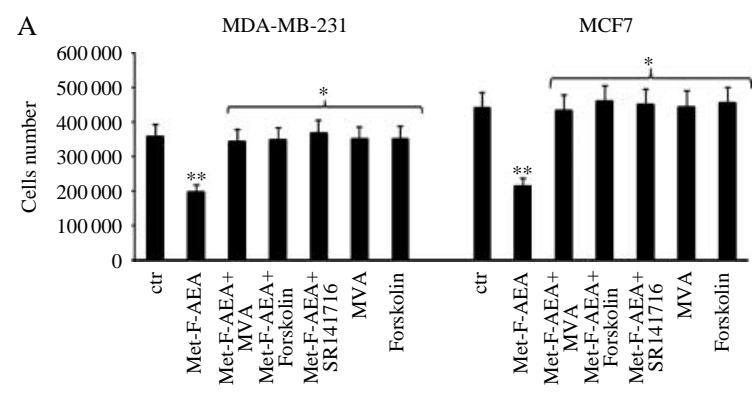

B

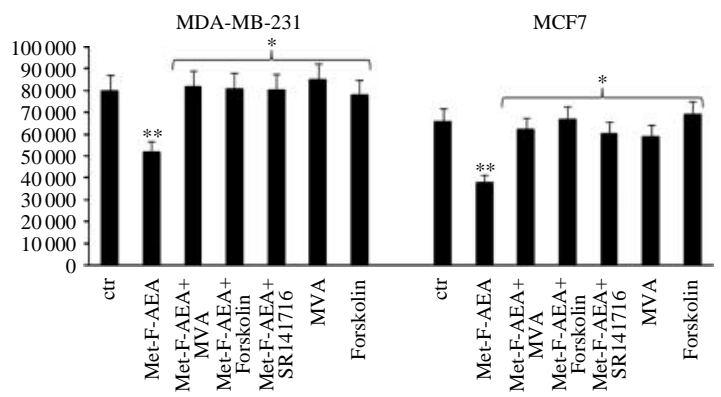

Figure 1 (A) Cell number of human breast cancer cells MDA-MB-231 and MCF7 by trypan blue dye exclusion assay. Cells $\left(5 \times 10^{4} /\right.$ well) were cultured in triplicate for $24 \mathrm{~h}$ with $10 \mu \mathrm{M}$ of Met-F-AEA. (B) Cells were cultured in triplicate with several drugs, and after 18-h incubation, $\left[{ }^{3} \mathrm{H}\right]$ thymidine incorporation $(0.5 \mu \mathrm{Ci} /$ well $)$ was measured. Co-addition of mevalonate at $700 \mu \mathrm{M}$, forskolin at $0.5 \mu \mathrm{M}$, and SR141716 at $0.1 \mu \mathrm{M}$ recovered the inhibition of cell proliferation. Data represent results from at least three separate experiments each performed in triplicate. The graph reports the mean \pm s.D. values of three independent experiments. Inhibition of proliferation was statistically significant. Met-F-AEA data were compared to the controls, whereas all other treatments were compared to Met-F-AEA-treated cells. (with Student's $t$-test ${ }^{\star \star} P<0.0001,{ }^{*} P<0.001$, Met-F-AEA versus control).

in a dose-dependent manner. We observed that the maximal inhibition occurred at $10 \mu \mathrm{M}$ of Met-F-AEA after $24 \mathrm{~h}$. The arrest of cell growth was reverted by the CB1 receptor antagonist SR141716 at $0.1 \mu \mathrm{M}$, suggesting that this effect was mediated by the CB1 receptor (De Petrocellis et al. 1998, Melck et al. 1999, Grimaldi et al. 2006, Laezza et al. 2006a,b). Moreover, we observed that the activation of CB1 receptor by the stable analog Met-F-AEA inhibited the activity of Ras and RhoA proteins (Bifulco et al. 2001, Laezza et al. 2008), two GTP-binding proteins whose activity are dependent on post-translational modification by an isoprenoid compound as FPP and GGPP. These isoprenoids are generated by the MVA pathway, where the endoplasmic reticulum enzyme HMG-CoA reductase catalyzes the synthesis of MVA, precursor of donor isoprenoids (Laezza et al. 2006a,b). Based on this background, we hypothesized that the activation of CB1 receptor could affect the activity of HMG-CoA reductase. First, we have studied if the arrest of cell growth by Met-F-AEA at $10 \mu \mathrm{M}$ was reverted by the concomitant addition of MVA at $700 \mu \mathrm{M}$, and of forskolin at $0.5 \mu \mathrm{M}$, an activator of AC (Bosier et al. 2009), at Met-F-AEA-treated cells. As shown in Fig. 1A and B, the co-addition of MVA and forskolin at treated cells recovered the cell proliferation. Because the synthesis of MVA is catalyzed by HMG-CoA reductase (Goldstein \& Brown 1990), we evaluated whether the activation of $\mathrm{CB} 1$ receptor affected the activity of the enzyme by performing an assay of HMG-CoA reductase activity in cells treated with Met-F-AEA at $10 \mu \mathrm{M}$ for $24 \mathrm{~h}$. As shown in Fig. 2, the CB1 activation by Met-F-AEA decreased the HMG-CoA reductase activity in MDA-MB-231 and MCF7 cells after $24 \mathrm{~h}$ of treatment reaching the $45 \%$ of reduction of activity after $48 \mathrm{~h}$ of treatment. This effect was reverted both by co-treatment with forskolin at $0.5 \mu \mathrm{M}$ and SR141716 at $0.1 \mu \mathrm{M}$, antagonist of CB1 receptor. In order to ascertain if the reduction of HMG-CoA activity was dependent on the mRNA expression of this gene, we analyzed the mRNA levels using quantitative RT-PCR. Treatment with Met-F-AEA caused a decline in mRNA levels of both cell lines in comparison with control, and the effect was reverted when the cells were co-treated with forskolin at $0.5 \mu \mathrm{M}$ or SR141716 at $0.1 \mu \mathrm{M}$ (Fig. 3A and B). To assess if the effect of Met-F-AEA on HMG-CoA reductase activity was due to the expression levels of HMG-CoA reductase protein, we performed a western blot analysis of microsomal protein isolated from both cell lines treated with Met-F-AEA. We observed that the Met-F-AEA

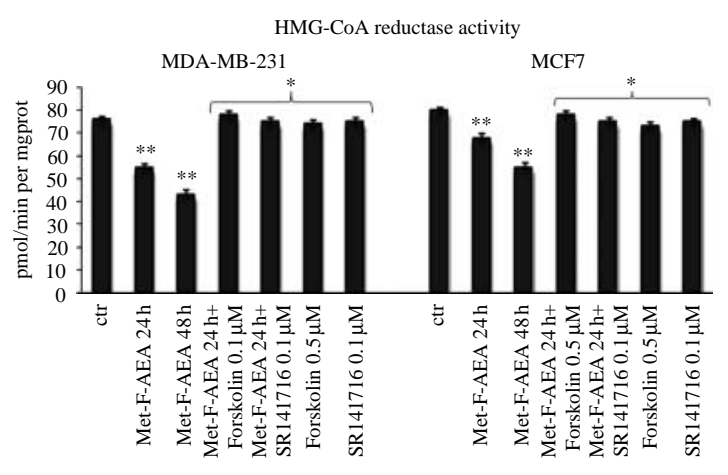

Figure 2 Effect of Met-F-AEA on HMG-CoA reductase activity of MDA-MB-231 and MCF7 cell lines. In vitro HMG-CoA reductase activity was evaluated in microsomes, after incubation with Met-F-AEA $10 \mu \mathrm{M}$ after 24 and $48 \mathrm{~h}$. Co-addition of forskolin at $0.5 \mu \mathrm{M}$ or SR141716 at $0.1 \mu \mathrm{M}$ after $24 \mathrm{~h}$ recovered the HMG-CoA reductase activity. The value is expressed as percent of control sample assumed as $100 \%$. The data were expressed as mean \pm s.D. The picture presented is representative of three different experiments. ${ }^{\star \star} P<0.001$ and ${ }^{\star} P<0.01$ as compared to control. 

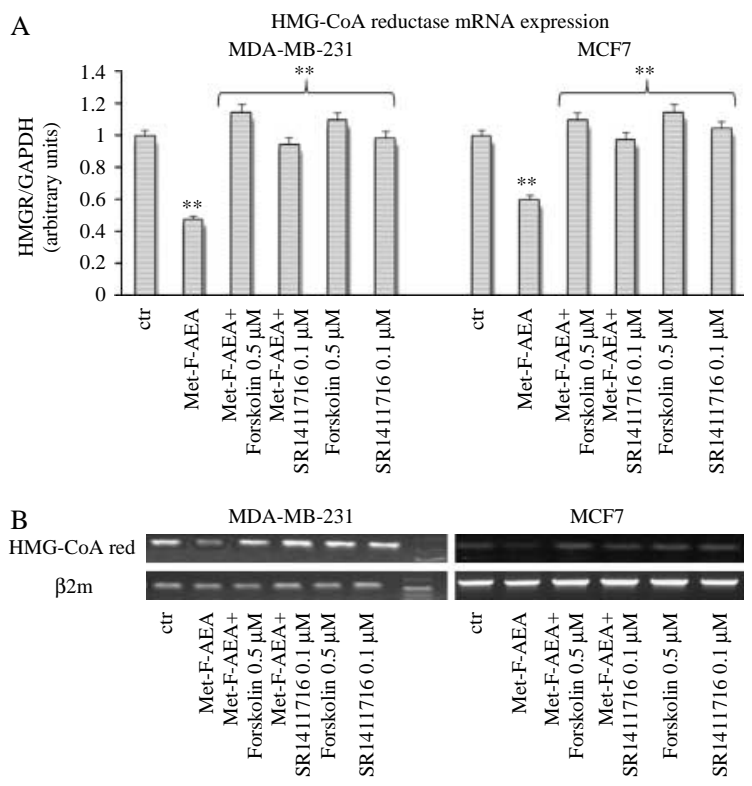

Figure 3 Effect of Met-F-AEA on mRNA expression of HMG-CoA reductase of MDA-MB-231 and MCF7 cell lines.

(A) Ratio of HMG-CoA reductase and $\beta 2 m$ densitometric analysis. Cells were grown in cell culture dishes for $24 \mathrm{~h}$ and were then exposed to several drugs for $24 \mathrm{~h}$ followed by total RNA isolation and quantitative RT-PCR. (B) Representative u.v. exposure of HMG-CoA reductase CDNA on $1.5 \%$ agarose gel. Data shown in A are means \pm s.E.M. of three samples. Each bar represents the mean \pm S.D. of three different experiments. ${ }^{\star \star} P<0.05$ versus control.

treatment evoked a significant decrease in protein levels in treated cells in comparison with control cells, and they were recovered in cells co-treated with forskolin and SR141716 (Fig. 4A).

\section{Met-F-AEA inhibited the activity of transcription factor CREB}

In the previous section, we observed that forskolin at $0.5 \mu \mathrm{M}$ recovered cell proliferation activity, mRNA and protein levels of HMG-CoA reductase of Met-F-AEA-treated cells. Forskolin, an activator of AC, causes an increase of cAMP levels which is translated into pleiotropic intracellular effects by a panel of cAMP-binding effector proteins, which include cAMP-dependent protein kinase A (PKA) and members of the CREB protein family. The CREB protein, primarily regulated via cAMP/PKA-dependent phosphorylation, has been recognized as an important transcription factor involved in the control of HMG-CoA reductase gene transcription; moreover, we described that TSH, enhancing cAMP production, induced an increase of HMG-CoA reductase gene expression by activation of CREB protein (Bifulco et al. 1995). As recent reports described that activation of cannabinoid receptors leads to the regulation of CREB protein (Herring et al. 1998), we investigated whether the CB1 activation by Met-F-AEA affected the activity, using an anti-phospho-CREB (Ser 133), and the expression of CREB protein by western immunoblotting analysis. As shown in Fig. 4B in the lysates of Met-F-AEA-treated cells, we revealed a significant decrease in the levels of phosphorylated CREB after $1 \mathrm{~h}$ in comparison with untreated cells, while co-treatment of cells with forskolin or SR141716 increased the levels of phosphorylated CREB in comparison with Met-F-AEA-treated cells. The levels of CREB protein did not change in the treated cells in comparison with control cells.

\section{Met-F-AEA inhibited the protein prenylation}

As the activation of $\mathrm{CB} 1$ receptor inhibited the HMG-CoA reductase activity by reducing the synthesis of downstream products as FPP and GGPP required for the prenylation of proteins, we analyzed the pattern of prenylated proteins in Met-F-AEAtreated cells. We metabolically labeled these cells with $\left[{ }^{3} \mathrm{H}\right]$-MVA a labeled precursor of both cholesterol and several isoprenoid intermediates. To allow the incorporation of $\left[{ }^{3} \mathrm{H}\right]-\mathrm{MVA}$ into prenylated proteins, endogenous MVA synthesis was blocked by the addition of $10 \mu \mathrm{M}$ lovastatin, a specific inhibitor

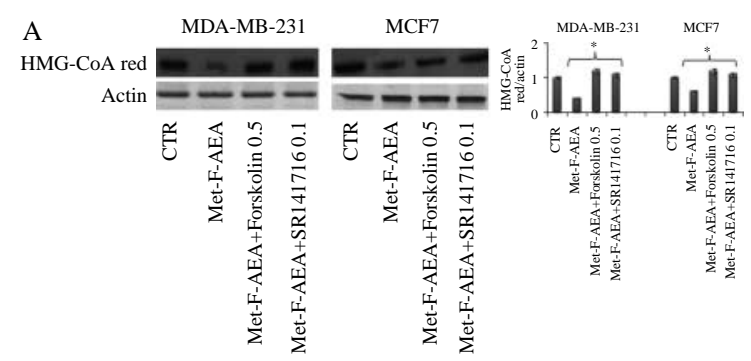

B

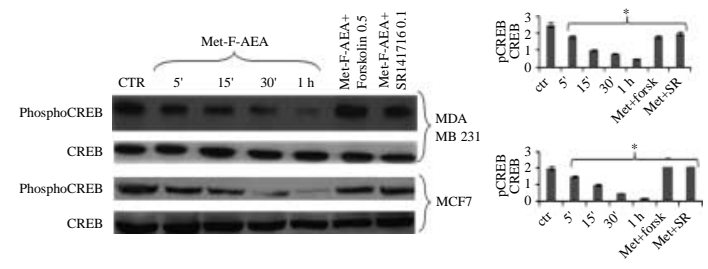

Figure 4 (A) Western blot and densitometric analysis of HMG-CoA reductase protein in MDA-MB-231 and MCF7 cells treated with Met-F-AEA at $10 \mu \mathrm{M}$, forskolin at $0.5 \mu \mathrm{M}$, and SR141716 at $0.1 \mu \mathrm{M}$. (B) Western blot and densitometric analysis of phospho-CREB protein levels in MDA-MB-231 cells. The cells were incubated with Met-F-AEA for the times indicated. Co-addition of forskolin at $0.5 \mu \mathrm{M}$ or SR141716 at $0.1 \mu \mathrm{M}$ for $1 \mathrm{~h}$ recovered the phosphorylation levels of CREB protein. The picture presented is representative of three different experiments. ${ }^{\star \star} P<0.001$, as compared to control; ${ }^{\star} P<0.01$. 


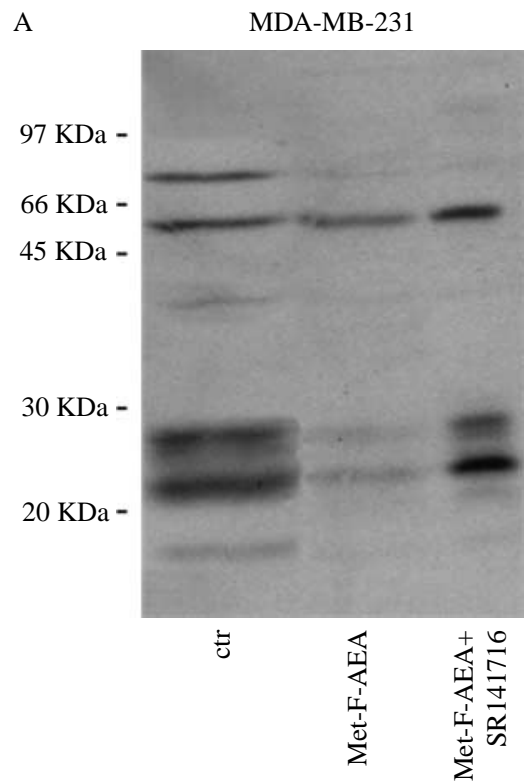

B

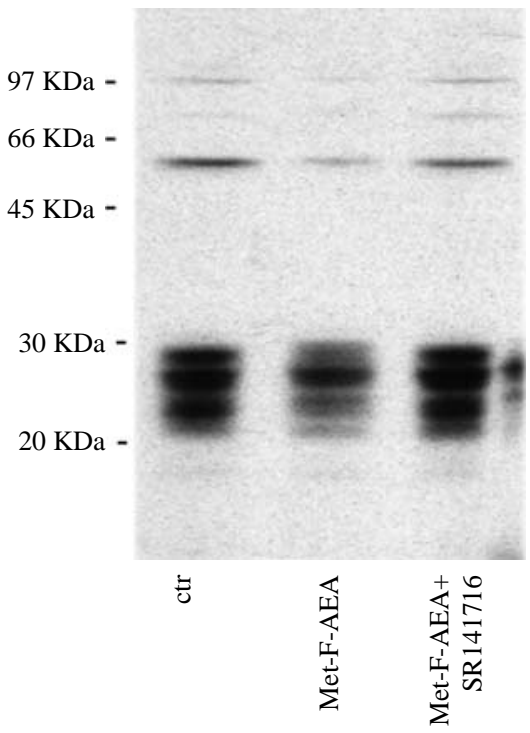

Figure 5 Incorporation of (RS)-[5- $\left.{ }^{3} \mathrm{H}\right]$-mevalonolactone into protein in MDA-MB-231 (A) and MCF7 (B) cells. Cells were treated with Met-F-AEA at $10 \mu \mathrm{M}$ and Met-F-AEA plus SR141716 at $0.1 \mu \mathrm{M}$ for $24 \mathrm{~h}$. Whole cell extracts were analyzed by SDS-PAGE and fluorography; $100 \mu \mathrm{g}$ of whole cell protein were loaded onto each lane. These data are representative of three independent experiments.

The autoradiogram was exposed for 20 days.

of HMG-CoA reductase (Laezza et al. 2006a,b). Under these conditions, MDA-MB-231 (Fig. 5A) and MCF7 (Fig. 5B) cells incorporated $\left[{ }^{3} \mathrm{H}\right]$-MVA very efficiently. Radiolabeled proteins in cellular lysates are separated by electrophoresis showing a variety of proteins with a molecular weight ranging between 14 and $90 \mathrm{kDa}$ (Laezza et al. 2006a,b). Cells treated with
Met-F-AEA at $10 \mu \mathrm{M}$ for $24 \mathrm{~h}$ showed a decrease into the incorporation of the $\left[{ }^{3} \mathrm{H}\right]-\mathrm{MVA}$ into several cellular proteins. Cells exhibited a substantial decrease in the intensity of 46 and $68 \mathrm{kDa}$, and $20-30 \mathrm{kDa}$ protein bands (Fig. 5A and B), these latter include Ras and Rho proteins. The incorporation of $\left[{ }^{3} \mathrm{H}\right]-\mathrm{MVA}$ in prenylated proteins was reverted when cells were co-treated with SR141716 at $0.1 \mu \mathrm{M}$. The change in prenylation protein was not induced by a decrease of protein synthesis (data not shown).

\section{Met-F-AEA inhibited ras farnesylation}

As the translocation of Ras protein from the cytoplasm to the plasma membrane, an essential step for its biological activity, is dependent on farnesylation (Konstantinopoulos et al. 2007), we investigated if CB1 activation by Met-F-AEA affected Ras farnesylation by a specific immunoprecipitation with an anti-

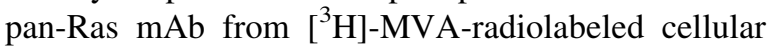
lysates treated with Met-F-AEA at $10 \mu \mathrm{M}$ for $24 \mathrm{~h}$ in comparison with untreated cellular lysates. As shown in Fig. 6A, Met-F-AEA lowered the prenylation level of Ras protein. In order to determine if Met-F-AEA treatment affected Ras membrane localization, we incubated MDA-MB-231 and MCF7 cells with Met-FAEA for $24 \mathrm{~h}$, and subsequently we determined Ras protein levels in cytosolic and membrane fractions by immunoblotting assay. Figure 6B shows that in control cells cultures, Ras is predominantly associated with the cell membrane fraction, while in cell cultures treated with Met-F-AEA, Ras is predominantly found in the cytosolic fraction, and the amount of Ras protein associated with the cell membrane is greatly reduced. Co-treatment with MVA at $700 \mu \mathrm{M}$ or with SR141716 at $0.1 \mu \mathrm{M}$ reverted this effect (Fig. 6B).

\section{Discussion}

In this study, we described a new role of the CB1 receptor in the regulation of the MVA pathway through the modulation of HMG-CoA reductase activity. The data presented in this report clearly reveal that the significant decrease in HMG-CoA reductase activity correlates well with the changes in the mRNA levels of this enzyme suggesting that the $\mathrm{CB} 1$ activation decreases the HMG-CoA reductase activity through its transcriptional regulation. The $\mathrm{CB} 1$ receptor is a member of the superfamily of G-protein-coupled receptors. The major mediators of $\mathrm{CB} 1$ receptor signaling are the Gi/o proteins of the G-protein family, which inhibit the adenylyl cyclase in most 

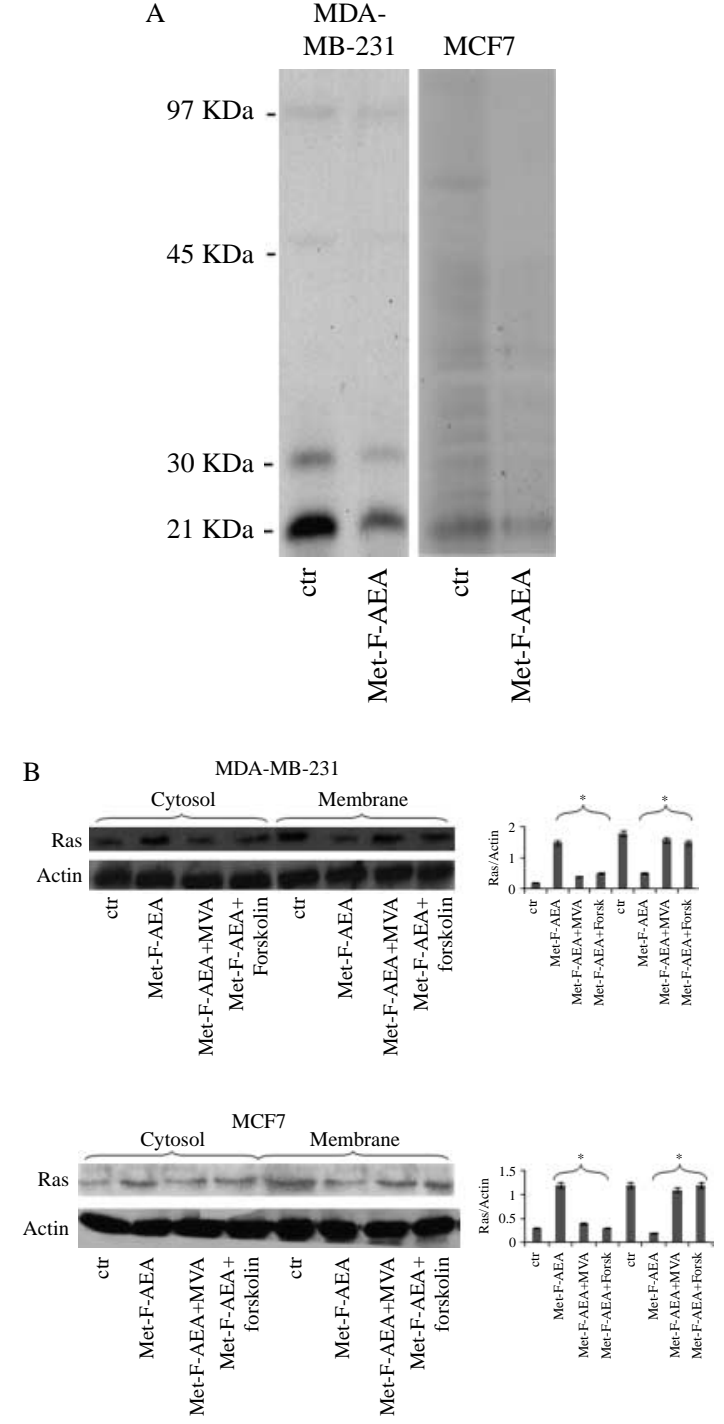

Figure 6 (A) Immunoprecipitation of ${ }^{3} \mathrm{H}-\mathrm{MVA}$-labeled Ras protein obtained from radiolabeled MDA-MB-231 and MCF7 cellular lysates with anti-pan-p21 ras mAb. The immunoprecipitates were subjected to SDS-PAGE. Autoradiogram was exposed for 20 days. (B) Met-F-AEA induced translocation of Ras protein from the cell membrane to cytosol. Western blots indicate the particulate fractions (cell membrane) and soluble fractions (cytosol) of MDA-MB-231 and MCF7 cells treated with Met-F-AEA at $10 \mu \mathrm{M}$, Met-F-AEA plus mevalonate at $700 \mu \mathrm{M}$, Met-F-AEA plus forskolin and untreated cells. Equal amounts of protein were loaded in each lane. Immunoblot analyses were performed using specific anti-pan-Ras and anti-actin antibodies as loading control. The experiments were performed at least three different times, and the results were always comparable. The figure shows a representative blot of three independent experiments. The intensities of the bands were expressed as arbitrary units and were calculated as mean ratio \pm s.D. of control protein (actin). The diagram shows quantification of the intensity of bands, calibrated to the intensity of the actin bands, expressed as means \pm S.E.M. $\left({ }^{*} P<0.05\right.$ for Met-F-AEA versus control). tissues and cells, and regulate ion channels, including calcium and potassium (Demuth \& Molleman 2006). Inhibition of $\mathrm{AC}$ activity was the first characterized agonist stimulated CB1 receptor signal transduction pathway (Howlett \& Fleming 1984). Several reports indicate that activation of cannabinoid receptors leads to the regulation of several DNA-binding proteins, including AP-1 (Porcella et al. 1998) and CREB protein (Herring et al. 1998). Recently, it has been reported that HU 210 and CP 55940, generally used as reference cannabinoid agonists, operate reciprocal influences on the expression of tyrosine hydroxylase (TH) through distinct regulations at the transcriptional level of the cis-enhancer elements AP-1 and CRE present in the TH gene promoter, suggesting that both CRE and AP-1 activities are regulated through activation of Gi/o-type G-proteins coupled to the CB1 receptor (Bosier et al. 2008, 2009). In the present study, we observed that the activation of the CB1 receptor by Met-F-AEA inhibited the phosphorylation of CREB protein essential for the activation of this transcription factor, and this effect was reverted in cells co-treated with forskolin that induced CREB phosphorylation through an increase in cAMP levels. In the past, we described that in the promoter region of HMG-CoA reductase, there exists a CRE site that is an important co-activator for transcriptional regulation of HMG-CoA reductase gene expression; moreover, we observed that TSH, a physiologic mitogen of thyroid cells, enhanced the production of cAMP, and induced an increase of HMG-CoA reductase gene expression by activation of CREB protein (Bifulco et al. 1995, Perillo et al. 1995). These results support the hypothesis that the CB1 activation through the regulation of the cis-enhancer element CRE present in the HMG-CoA reductase gene promoter could inhibit the transcription of this gene as a consequence of the HMG-CoA reductase protein levels determining a decrease of its activity. Moreover, we observed that the inhibition of cell proliferation upon CB1 activation is reversed by the addition of MVA. MVA is synthesized from HMG-CoA reductase, the rate-limiting enzyme of the MVA pathway. This pathway performs several key functions within cells, leading to the production of sterols, such as cholesterol essential to membrane formation, and isoprenoids. The isoprenoids are essential for switching on the function of GTPase proteins by post-translational lipid modifications - a process known as 'prenylation'. These modifications include the covalent attachment of a nonsterol isoprenoid (either FPP or GGPP) to the cysteine residue of the CAAX motif by farnesylation and geranylgeranylation respectively (McTaggart 2006). 
In this study, we focused on the inhibition of prenylation protein and in particular of Ras farnesylation because the Ras proteins (H-Ras, N-Ras, $\mathrm{K}-\mathrm{Ras} 4 \mathrm{~A}$, and K-Ras4B) are generally considered key molecular targets in the signal transduction pathways leading to cell proliferation, differentiation, or death. Ras is also involved in uncontrolled growth. Indeed, an increased expression of normal or mutated ras has been observed in 30-40\% of human cancers, including colon cancer, pancreatic, breast carcinoma, and anaplastic and follicular thyroid carcinoma (Laezza et al. 1998). The Ras farnesylation is essential to target this protein to the membrane where it performs its biological activity. In a previous study, we observed that anandamide may be efficacious for the inhibition of K-ras-induced epithelial cancer cell growth in vivo through the activation of $\mathrm{CB} 1$ receptors, inhibition of p21ras activity and blockade of the cell cycle (Laezza et al. 1998). Here we have observed that the inhibition of p21ras activity is due to the inhibition of its farnesylation, which allows the translocation of this protein from cytosol to cell membrane. These data strongly suggest that the inhibition of the farnesylation of Ras protein is critical for its biological activity and consequently for cancer cell proliferation. So, the crucial point of the antitumor action of Met-F-AEA could be related to the inhibition of Ras farnesylation, causing the disruption of Ras localization to the membrane, required to modulate its interaction with upstream and downstream signaling components, thereby attenuating the ability of Ras protein to promote cell proliferation. Finally, we observed that CB1 receptor agonists emulate other inhibitors of prenylation protein, as lovastatin and/or bisphosphonates (Graaf et al. 2004) in both cancer cell lines (data not shown) The finding of possible antitumor effect for these substances might have a tremendous potential for therapeutic intervention in preventing the progression of breast cancer.

\section{Declaration of interest}

The authors declare that there is no conflict of interest that could be perceived as prejudicing the impartiality of the research reported.

\section{Funding}

Grant sponsors: Sanofi-aventis; Associazione Educazione e Ricerca Medica Salernitana ERMES.

\section{References}

Bifulco M \& Di Marzo V 2002 Targeting the endocannabinoid system in cancer therapy: a call for further research. Nature Medicine 6 547-550.

Bifulco M, Perillo B, Saji M, Laezza C, Tedesco I, Kohn LD \& Aloj SM 1995 Regulation of 3-hydroxy-3methylglutaryl coenzyme A reductase gene expression in FRTL-5 cells. I. Identification and characterization of a cyclic AMP-responsive element in the rat reductase promoter. Journal of Biological Chemistry 270 15231-15236.

Bifulco M, Laezza C, Portella G, Vitale M, Orlando P, De Petrocellis L \& Di Marzo V 2001 Control by the endogenous cannabinoid system of ras oncogenedependent tumor growth. FASEB Journal 15 2745-2747.

Bifulco M, Laezza C, Pisanti S \& Gazzerro P 2006 Cannabinoids and cancer: pros and cons of an antitumour strategy. British Journal of Pharmacology 148 123-135.

Bifulco M, Malfitano AM, Pisanti S \& Laezza C 2008 Endocannabinoids in endocrine and related tumours. Endocrine-Related Cancer 15 391-408.

Bosier B, Hermans E \& Lambert D 2008 Differential modulation of AP-1- and CRE-driven transcription by cannabinoid agonists emphasizes functional selectivity at the CB1 receptor. British Journal of Pharmacology 155 24-33.

Bosier B, Hermans E \& Lambert DM 2009 Concomitant activation of adenylyl cyclase suppresses the opposite influences of $\mathrm{CB}(1)$ cannabinoid receptor agonists on tyrosine hydroxylase expression. Biochemical Pharmacology 15 216-227.

Brown MS, Goldstein JL \& Dietschy JM 1979 Active and inactive forms of 3-hydroxy-3-methylglutaryl CoA reductase. Journal of Biological Chemistry 254 5144-5149.

Demuth DG \& Molleman A 2006 Cannabinoid signalling. Life Sciences 78 549-563.

De Petrocellis L, Melck D, Palmisano A, Bisogno T, Laezza C, Bifulco M \& Di Marzo V 1998 The endogenous cannabinoid anandamide inhibits human breast cancer cell proliferation. PNAS $958375-8380$.

Goldstein JL \& Brown MS 1990 Regulation of the mevalonate pathway. Nature 343 425-430.

Graaf MR, Richel DJ, van Noorden CJF \& Guchelaar HJ 2004 Effects of statins and farnesyltransferase inhibitors on the development and progression of cancer. Cancer Treatment Reviews 30 609-641.

Grimaldi C, Pisanti S, Laezza C, Malfitano AM, Santoro A, Vitale M, Caruso MG, Notarnicola M, Iacuzzo I, Portella G et al. 2006 Anandamide inhibits adhesion and migration of breast cancer cells. Experimental Cell Research 312 363-373.

Herring AC, Koh WS \& Kaminski NE 1998 Inhibition of the cyclic AMP signaling cascade and nuclear factor binding to $\mathrm{CRE}$ and $\kappa \mathrm{B}$ elements by cannabinol, a minimally CNS-active cannabinoid. Biochemical Pharmacology 55 1013-1023. 
Howlett AC \& Fleming RM 1984 Cannabinoid inhibition of adenylate cyclase. Pharmacology of the response in neuroblastoma cell membranes. Molecular Pharmacology 26 532-538.

Konstantinopoulos PA, Karamouzis MV \& Papavassiliou AG 2007 Post-translational modifications and regulation of the RAS superfamily of GTPases as anticancer targets. Nature Reviews. Drug Discovery 6 541-555.

Laezza C, Di Marzo V \& Bifulco M 1998 v-K-ras leads to preferential farnesylation of $\mathrm{p} 21$ (ras) in FRTL-5 cells: multiple interference with the isoprenoid pathway. PNAS 95 13646-13651.

Laezza C, Notarnicola M, Caruso MG, Messa C, Macchia M, Bertini S, Minutolo F, Portella G, Fiorentino L, Stingo S et al. 2006a N6-isopentenyladenosine arrests tumor cell proliferation by inhibiting farnesyl diphosphate synthase and protein prenylation. FASEB Journal $20412-418$.

Laezza C, Pisanti S, Crescenzi E \& Bifulco M 2006b Anandamide inhibits $\mathrm{Cdk} 2$ and activates Chk1 leading to cell cycle arrest in human breast cancer cells. FEBS Letters 580 6076-6082.

Laezza C, Pisanti S, Malfitano AM \& Bifulco M 2008 The anandamide analog, Met-F-AEA, controls human breast cancer cell migration via the RHOA/RHO kinase signaling pathway. Endocrine-Related Cancer 15 965-974.

McTaggart SJ 2006 Isoprenylated proteins. Cellular and Molecular Life Sciences 63 255-267.

Melck D, Rueda D, Galve-Roperh I, De Petrocellis L, Guzman M \& Di Marzo V 1999 Involvement of the $\mathrm{cAMP} /$ protein kinase A pathway and of mitogen-activated protein kinase in the anti-proliferative effects of anandamide in human breast cancer cells. FEBS Letters 463 235-240.

Mondola $\mathrm{P}$, Serù R, Santillo M, Damiano S, Bifulco M, Laezza C, Formisano P, Rotilio G \& Ciriolo MR 2002 Effect of $\mathrm{Cu}, \mathrm{Zn}$ superoxide dismutase on cholesterol metabolism in human epatocarcinoma (HepG2) cells. Biochemical and Biophysical Research Communications 295 603-609.

Nakanish M, Goldstein JL \& Brown MS 1988 Multivalent control of 3-hydroxy-3-methylglutaryl coenzyme A reductase. Journal of Biological Chemistry 263 8929-8937.

Ngo TT, Bennett MK, Bourgeois AL, Toth JI \& Osborne TF 2002 A role for cyclic AMP response elementbinding protein (CREB) but not the highly similar ATF-2 protein in sterol regulation of the promoter for 3-hydroxy-3-methylglutaryl coenzyme A reductase. Journal of Biological Chemistry 277 33901-33905.

Perillo B, Tedesco I, Laezza C, Santillo M, Romano A, Aloj SM \& Bifulco M 1995 Regulation of 3-hydroxy-3methylglutaryl coenzyme A reductase gene expression in FRTL-5 cells. II. Down-regulation by v-K-ras oncogene. Journal of Biological Chemistry 270 15237-15241.

Porcella A, Gessa GL \& Pani L 1998 Delta9-tetrahydrocannabinol increases sequence-specific AP-1 DNA-binding activity and Fos related antigens in the rat brain. European Journal of Neuroscience $\mathbf{1 0}$ 1743-1751.

Sands WA \& Palmer TM 2008 Regulating gene transcription in response to cyclic AMP elevation. Cellular Signalling 20 460-466. 